\title{
CORRESPONDENCE
}

To the Editor of the AEronautical Journal

\section{ARMY AEROPLANE TRIALS}

Sir,-Now that Mr. Berriman's paper is in print it is possible to comment on it more systematically than was possible at short notice at the Meeting itself.

It will be noticed that he has at his disposal only equations (3), (5), (6), (7), p. 242. He might have written these in the more usual form

$$
\begin{aligned}
& \text { Total weight } \mathrm{Z}=\mathrm{K}_{\mathrm{y}} \mathrm{SV}^{\mathrm{L}} \quad=\mathrm{c}_{\mathbf{y}}{ }^{2} \quad \text { (5) and (3) } \\
& \text { Motor horse-power } \mathrm{x}=\mathrm{K}_{\mathrm{x}} \mathrm{SV}^{2} \div 75 \rho \\
& \text { Surface } \mathrm{S}=\mathrm{y}^{2} \\
& \text { whence } W_{1}=\frac{Z}{x}=\frac{75 K_{y}}{K_{x}} \times \frac{1}{V} \\
& \mathrm{~W}_{2}=\frac{\mathrm{Z}}{\mathrm{S}}=\mathrm{K}_{\mathrm{y}} \mathrm{V}^{2} \\
& \text { " } \mathrm{x} "=\mathrm{W}_{1} \mathrm{~W}_{2}=\frac{\mathrm{Z}^{2}}{\mathrm{xS}}=\frac{75 \rho \mathrm{K}_{\mathrm{y}}{ }^{2}}{\mathrm{~K}_{\mathrm{x}}} \mathrm{V} \\
& \text { His " } \mathrm{k} \text { " is } \frac{75 \rho \mathrm{K}_{\mathrm{y}}{ }^{2}}{\mathrm{~K}_{\mathrm{x}}}
\end{aligned}
$$

The dimensions of 75 and $\rho$ are zero as both are numerical ratios.

$$
\begin{aligned}
& \text { The dimensions of } \mathrm{K}_{\mathrm{x}} \text { and } \mathrm{K}_{\mathrm{y}} \text { are } \frac{\text { Weight }}{\text { Surface } \times \text { velocity square }} \\
& \qquad=\left(\frac{\mathrm{mlt}-\mathrm{t}}{l^{2} \times l^{2} \mathrm{t}^{-2}}\right)=\left(\frac{\mathrm{m}}{l^{3}}\right)=\text { densityr. }
\end{aligned}
$$

Hence the dimensions of $\mathrm{k}$ are also that of density, so that $\mathrm{X}=\mathrm{kV}$ has the dimen. sions of density and velocity $=\left(\mathrm{ml}^{-3} \times \mathrm{lt}^{-1}\right)=\left(\mathrm{ml}^{-2} \mathrm{t}^{-1}\right)$ not of density $\times$ hyperaccelerntion as the writer incorrectly stated on page 240 .

$$
\begin{gathered}
\text { His } \mathrm{W}_{:}=\mathrm{f} \mathrm{V}^{-1}=\left(\frac{75 \rho \mathrm{K}_{\mathrm{s}}}{\mathrm{K}_{\mathrm{x}}} \frac{1}{\mathrm{~V}}\right) \\
\mathrm{W}_{2}=\mathrm{fV}^{2}=\left(\mathrm{K}_{\mathrm{y}} \mathrm{V}^{2}\right) \\
\therefore \mathrm{W}_{1} \mathrm{~W}_{2}=\mathrm{f} \mathrm{V}^{-} \mathrm{f}^{2}=\mathrm{fV}
\end{gathered}
$$

remind one of the late Professor Chrystal's Banker, whose conception of functionality was found on examination to be limited to that of simple proportionality.

Owing to the absence of the equations (1) and (2), page 24l, Mr. Berriman's hypothetical acroplane, when it varies, does so without regard for its factors of safety, and the limits imposed theseby on practical designers, while the absence of equations (4), (13) and (14), page 242 , leave him groping in the dark as to the direction in which to look for the best dimensions and best horse-power with the motors, materials, and methods of design at his disposal, and with the factors of safety permissible. 
To the Editor of the Aëronautical Jotrinai..

SIR,-Kindly print the following list of errata in the writer's "Note on Theory of Aeroplane Dimensions," October, 1912 :-

Page 241 : Eqns. (3) and (5) for " $\mathrm{z}$ " read " $\mathrm{Z}$." Footnote (1) for " $Z_{1}$ " read " $z_{1}$ "

Page 243 : Eqn. (1.7) for " $z_{10}$ " read " $Z_{0}$ " Eqn. (18) for " $K_{1}$ " read " $k_{1}$ " Eqn. (20) for " $\mathrm{Y}_{0}{ }^{3}$ " read " $\mathrm{y}_{0}{ }^{3}$ " for $\frac{1}{\mathrm{k}_{1}{ }^{3}} \operatorname{read} \frac{1}{\mathrm{k}_{2}{ }^{3}}$

Page 244 : Column 3 of table for " $Z$ " read " $z$."

Page 245: Line 6 to left-hand side of " $\mathrm{z}=$ etc." add the term "-400." Second paragraph, line 9, for " test gliding velocity" read " best gliding velocity."

Page 246: Ante-penultimate par. This is an obvious misreading of equation 19. For "High specific glider weight" read "low specific motor weight." Even this correction is inadequate, for the high loading of the Bristol is also in part due to the high value of $\mathrm{A}^{3}$, thit t, is, of $\mathrm{K}_{\mathrm{y}}{ }^{3} \div \mathrm{K}_{\mathrm{x}}{ }^{2}$.

A. R. LOW.

\section{NEW BOOKS AND PUBLICATIONS}

*Guide Pratique d'Aviation. Lieut. Sensever et Lieut. Péralda. Preface by Col. Hirschauer. Paris : Librairie Chapelot. 1912. pp. 201. Illus.

Aeronautical Engines. A. Graham Clark. London: Institution of Automobile Engineers. 1912.

*Les Hydea Éroplanes. F. R. Petit. Paris : H. Dunod et E. Pinat. 1912. pp. 84 . Illus. 3 francs.

*Les Hydro-aéroplanes. Pierre Rivière. Preface by Alphonse Tellier. Paris: Librairie Aernnautique. 1912. pp. 88. Illus. 3 francs.

En quor consiste la Stabilité. Alex. Sée. Paris : Gauthier-Villars. 1913. pp. 35. Figs.

Les Turbines ì Gaz. L. Ventou-Duclaux. Paris : H. Dunod et E. Pinat. 1912. pp. 128. Figs. 3 francs 75 .

Instructions Météorologiques. (5th edition). A. Angot. Paris: Gauthier-Villars. 1911. pp. 161. Figs.

Aéro-Mandel, 1912-13. Ch. Faroux et Et. Bernard. Paris: Dunod et Pinat, 1912. pp. 550. Figs. 10 francs.

Th. Scheimpilugs Landvermessung aus der Luft. G. Kammerer.

Bulletin de l'Institut AErodynamique de Koutchino. (Fascicule IV.) Moecou: I. N. Kouchnéreff et Cie. 1912. pp. 140. Figs.

Abrégé SUR L'Hélice et La Résistance de L'AIr. Maurice Gandillot. Paris : Gauthier-Villars. 1912. pp. 188. Figs. 8s.

Die Arbeiten des Königl. Preuzischex Aeronautischen Observatoriums bei Lindexberg IM JAHRE 1911. Dr. Richard Assmanr. Braunschweig: Friedr. Vieweg ind Sohn. 1912. pp. 287. Figs. 15 Mark.

* Review appears in this issue. 